\title{
Peningkatan Kapasitas Kurikulum 2013 Pendidikan Usia Dini Pada Guru dan Pengelola PAUD Al Birru Nasyiatul Aisyiyah
}

\author{
Risni Julaeni Yuhan ${ }^{1}$, Diah Puspitarini ${ }^{2}$, Husnul Khotimah ${ }^{3}$, Lia Karisma ${ }^{4}$, Fauzah R.K ${ }^{5}$, \\ Hanifah Kasih $\mathrm{S}^{6}$, Emi Rahmawati ${ }^{7}$ \\ ${ }^{1}$ Politeknik Statistika STIS; ${ }^{2}$ Universitas Ahmad Dahlan; \\ 3,4,5,6,7 Pimpinan Pusat Nasyiatul Aisyiah \\ risnij@stis.ac.id
}

Submitted: $31^{\text {st }}$ July 2019. Revised: $11^{\text {th }}$ October 2019. Accepted: $31^{\text {st }}$ October 2019

Key word:

Curriculum

2013; early

childhood;

Nasyiatul

Aisyiyah

\section{Kata Kunci}

Kurikulum 2013;

PAUD;

Nasyiatul

Aisyiyah

\section{Abstract}

Early Childhood Education (PAUD) is an embryo of children's education in shaping a generation of people who are superior and dignified. Education provided to children aged 0-6 years primarily introduces physical activity to stimulate the child's motoric development, affection and introduce the process of socializing to children. Considering the importance of PAUD, the curriculum 2013 PAUD has now been developed, where previously there was no specific curriculum that could be used in the learning process in PAUD. Applying the curriculum 2013, the teachers still did not have enough capacity to be able to translate the concepts of the curriculum into the learning process. Therefore, training was carried out in an effort to increase capacity in the application of the Curriculum 2013 PAUD. The analytical method used is descriptive analysis and inference. The result of this activity is that there is a change in knowledge about the 2013 PAUD curriculum for the training participants. Participants give evaluators on the implementation of training in general is good. Outcome of this training the participants are required to disseminate the curriculum 2013 PAUD material.

\section{Abstrak}

Pendidikan Anak Usia Dini (PAUD) merupakan embrio pendidikan anak dalam membentuk generasi bangsa yang unggul dan bermartabat. Pendidikan yang diberikan kepada anak usia 0-6 tahun utamanya mengenalkan aktivitas fisik untuk merangsang perkembangan motorik anak, afeksi serta mengenalkan proses bersosialisasi pada anak. Mengingat pentingnya PAUD maka pada saat ini telah dikembangkan kurikulum PAUD Tahun 2013, dimana sebelumnya belum ada kurikulum khusus yang dapat digunakan dalam proses pembelajaran di PAUD. dalam mengaplikasikan kurikulum 2013, para guru masih belum memiliki kapasitas yang cukup untuk dapat menterjemahkan konsep dari kurikulum tersebut kedalam proses pembelajaran. Oleh karena itu dilakuakn pelatihan dalam upaya peningkatan kapasistas dalam penerapan Kurikulum 2013 PAUD. Metode analisis yang diguanakn adalag analisis deskriptif dan inferensia. Hasil dari kegiatan ini adalah terdapat perubahan pengetahuan tentang kurikulum 2013 PAUD pada para peserta pelatihan. Peserta memberikan penilai terhadap pelaksanan pelatihan pada umumnya baik. Luaran dari pelatihan ini para peserta wajib melakukan sosialisasi materi kurikulum PAUD 2013. 


\section{PENDAHULUAN}

\section{Pendidikan Anak Usia Dini} (PAUD) merupakan embrio pendidikan anak dalam membentuk generasi bangsa yang unggul dan bermartabat. Pendidikan yang diberikan kepada anak usia 0-6 tahun utamanya mengenalkan aktivitas fisik untuk merangsang perkembangan motorik anak, afeksi serta mengenalkan proses bersosialisasi pada anak. Generasi yang kompeten akan dapat meningkatkan kualitas generasi bangsa semakin maju dan meningkatkan pembangunan sumberdaya manusia yang berkualitas. Menurut Undang-undang Sistem pendidikan Nasional No. 20 tahun 2003, Pendidikan anak usia dini adalah suatu upaya pembinaan yang ditujukan kepada anak sejak lahir sampai dengan usia enam tahun yang dilakukan melalui pemberian rangsangan pendidikan untuk membantu pertumbuhan dan perkembangan jasmani dan rohani agar anak memiliki kesiapan dalam memasuki pendidikan lebih lanjut.

\section{Pentingnya PAUD antara lain} PAUD dapat mengoptimalisasi tumbuh kembang anak saat berusia "emas", dapat meningkatkan kesiapan sekolah (school readiness), menjembatani kondisi rumah/ budaya keluarga dengan sekolah formal (SD) sehingga transisi ke SD menjadi lebih lancar, PAUD berdampak panjang pada akademik dan ekonomi, dan memberi dampak positif terhadap capaian akademik ketika anak berusia 15 tahun. Mengingat pentingnya PAUD maka pada saat ini telah dikembangkan kurikulum PAUD Tahun 2013, dimana sebelumnya belum ada kurikulum khusus yang dapat digunakan dalam proses pembelajaran di PAUD.

Dengan adanya Kurikulum PAUD Tahun 2013 maka pembelajaran akan lebih terarah dan tercapainya pengembangan Anak Usia Dini Holistik_integratif (PAUD-HI). PAUD-HI merupakan pengembangan anak usia dini yang dilakukan untuk memenuhi kebutuhan esensial anak yang beragam dan saling berkait secara simultan dan sistematis, sehingga anak dapat tumbuh dan berkembang secara optimal sesuai dengan tahap perkembangan dan usianya (Direktorat PAUD\&DIKMAS, 2015).

Dalam mencapai tujuan pembelajaran dalam menumbuhkan dan mengembangkan seluruh potensi anak di usia emas diperlukan suatu sistem pembelajaran yang terencana dalam operasional, Perencanaan sistem pendidikan itulah yang disebut dengan kurikulum, Kurikulum merupakan seperangkat rencana dan pengaturan mengenai tujuan, isi, dan bahan pengembangan serta cara yang digunakan sebagai pedoman penyelenggaraan 
kegiatan pengembangan untuk mencapai tujuan pendidikan tertentu (Permen 146 tahun 2014),

Kurikulum PAUD yang terdiri dari seperangkat bahan pembelajaran yang mencakup lingkup perkembangan, yaitu perkembangan moral \& agama, fisikmotorik, kognitif, bahasa, dan sosial emosional, Kurikulum yang digunakan pada saat ini adalah kurikulum PAUD 2013, Kurikulum PAUD 2013 pada hakikatnya merupakan seperangkat rencana yang akan dilakukan selama proses pembelajaran, sehingga mutlak diperlukan oleh setiap satuan pendidikan, Kurikulum PAUD disiapkan oleh satuan PAUD yang bersangkutan sesuai dengan kebutuhan anak dengan mengacu pada dalam Permen No, 137 Tahun 2014 tentang Standar PAUD, Setiap anak diberi kesempatan untuk mengembangkan diri sesuai potensi masing-masing, Pendidik bertugas membantu, jika anak membutuhkan, Selain itu dalam kurikulum 2013 ini setiap Lembaga PAUD dapat mengembangkan kurikulum sendiri sesuai dengan ciri lembaga masing-masing dengan memenuhi prinsip dan capaian perkembangan minimal yang tertera dalam Permendiknas No, 137

Tahun 2014 tentang Standar PAUD, sebagai acuan,

Secara substansi operasional PAUD Al Birru Nasyiatul Aisyiyah sudah menerapkan kurikulum PAUD 2013, namun dalam pelakanaannya masih belum optimal dikarenakan beberapa permasalahan yang dihadapi. Secara garis besar masalah yang dihadapi dalam pengembangan PAUD Al Birru Nasyiatul Aisyiyah yaitu input, proses, dan output, Permasalahan terkait dengan input yaitu adanya keterbatasan dalam sumber daya pengajar. Keterbatasan ini dikarenakan tidak semua staf pengajar di PAUD Al Birru Nasyiatul Aisyiyah memiliki latar belakang pendidikan usia dini, Oleh karena itu dalam mengaplikasikan kurikulum 2013, para guru masih belum memiliki kapasitas yang cukup untuk dapat menterjemahkan konsep dari kurikulum tersebut kedalam proses pembelajaran.

Anak merupakan subyek penting dalam proses belajar-mengajar di sekolah, Sedangkan guru adalah salah satu sumber belajar yang secara langsung berhadapan dengan anak dalam proses tersebut, Dalam kaitan tersebut, maka guru perlu senantiasa melakukan up grading secara terus menerus termasuk dalam hal mendapatkan metode, pendekatan, atau cara yang tepat dalam pembelajaran, karena hanya dengan cara yang tepat maka tujuan dan hasil belajar mengajar dapat diwujudkan, Dalam upaya peningkatan kapasitas guru, oleh karena itu Pimpinan Pusat Nasyiatul Aisyiyah (PPNA) memandang perlu 
adanya perbaikan dalam bidang pendidikan usia dini dengan melakukan pelatihan kurikulum PAUD 2013, sehingga tujuan untuk mewujudkan Generasi Unggul, Mandiri dan Islami dapat tercapai lebih optimal. Pelatihan kurikulum ini dilakukan dengan bekerja sama dengan Kementerian Pendidikan dan Kebudayaan Republik Indonesia.

Kurikulum merupakan salah satu hal penting dalam preose belajar mengajar, karena dalam kurikulum ini berisi petunjuk dan ruang lingkup mata ajar yang harus diberikan kepada para siswa. Berdasarkan beberapa definisi kurikulum dapat diartikan sebagai pedoman dalam merencanakan program pembelajaran secara menyeluruh yang terdiri dari pengalaman belajar, materi pembelajaran yang disesuaikan dengan tahapan perkembangan anak melalui proses pembelajaran di dalam atau di luar sekolah yang masih berada dalam pengawasan sekolah. Menurut Ayob, dkk (2016) kurikulum yang telah dirancang bertujuan memberikan pengajaran, pengasuhan dan pendidikan untuk membina keperibadian anak, serta perkembangan bidang-bidang lain.

Kurikulum 2013 yang diterapkan di PAUD bertujuan untuk mendorong perkembangan peserta didik secara optimal melalui pengalaman belajar yang bermakna dan menyenangkan sehingga anak

mencapai kompetensi sikap, pengetahuan, dan keterampilan yang mendukung keberhasilan di sekolah dan pendidikan pada tahap selanjutnya (Direktorat PPAUD, 2015). Kurikulum PAUD Tahun 2013 ini dikembangkan berdasarkan kerangka dasar filosofis, sosiologis, teoritis, psikologis-pedagogis dan yuridis. Dengan struktur kurikulum 2013 PAUD yang terdiri dari muatan kurikulum, kompetensi diri, kompetensi dasar dan lam belajar.

Manajemen pembelajaran adalah segala usaha pengaturan proses belajar mengajar dalam rangka tercapainya proses belajar mengajar yang efektif dan efisien. Pembelajaran pada anak usia dini pada hakikatnya adalah pengembangan kurikulum secara konkret berupa seperangkat rencana yang berisi sejumlah pengalaman belajar melalui bermain yang diberikan pada anak usia dini berdasarkan potensi dan tugas perkembangan yang harus di kuasainya dalam rangka pencapaian kompetensi yang di miliki oleh anak (Yuliani, 2011).

Manajemen

mencakup kegiatan pengorganisasian, pengendalian (pengarahan), dan pengevaluasian. Dalam manajemen pembelajaran yang menjadi manager adalah guru, sehingga guru memiliki wewenang dan tanggungjawab 
untuk melakukan beberapa langkah kegiatan. Dengan demikian seorang guru wajib untuk mampu memahami kurikulum pembelajaran.

\section{METODE}

Kegiatan pengabdian masyarakat yang dilakukan pada guru dan pengelola PAUD Al Birru Nasyiatul Aisyiyah yang bertempat di Kota Surabaya Jawa Timur. Kegiatan ini dilakukan dengan:

1. Observasi untuk memperoleh data informasi tentang kondisi subyek penelitian dan lokasi pelaksanaan pembelajaran di PAUD seperti kondisi kelas, penggunaan waktu, media dan sarana belajar seperti APE pembelajaran;

2. Seminar tentang Kurikulum 2013;

3. Pelatihan Kurikulum 2013.

\section{HASIL DAN PEMBAHASAN}

\section{Tahap Persiapan}

Tahap awal pelaksanaan kegiatan ini adalah tahapan persiapan berupa koordinasi Tim Panitia Pimpinan Pusat dan Pimpinan Wilayah Nasyiatul Aisyiah Jawa Timur. Pada tahap perencanaan ini muncul ide untuk mengawali kegiatan peningkatan kapasitas ini dengan Seminar Nasional Di Era Revolusi Industri 4,0. Setelah disepakatinya konsep kegiatan ini maka dilanjutkan pada tahap koordinasi kesiapan perangkat kegiatan. Dalam koordinasi, tercapai kesamaan penetapan tanggal kegiatan, tempat, susunan panitia dan rekruitmen peserta seminar nasional dan pelatihan kurikulum. Kegiatan selanjutnya dilakukan dengan konsolidasi kepada Gubernur Propinsi Jawa Timur berkaitan dengan akan diadakan kegiatan Kurikulum PAUD 2013 dan memintanya untuk penyampaian orasi Ilmiah tentang pendidikan Anak Usia Dini di acara Pembukaan Kegiatan.

Selain koordinasi internal, dalam persiapan kegiatan ini dilakukan koordinasi juga dengan pihak kementerian sebagai funding dalam kegiatan ini. Koordinasi ini antara lain terkait dengan mekanisme pengajuan bantuan hingga pada tahap pelaporan kegiatan. Tak lupa juga dalam persiapan ini kami selalu berkoordinasi dalam penyiapan konten pelatihan dengan materi yang disesuaikan dengan petunjuk teknis dari Kemendikbud RI Tahun 2019. Kami berusaha semaksimal mungkin mencari pemateri yang sesuai dengan kriteria yang diharapkan oleh pihak enterian. Selain dengan pihak kementerian kami pun berkoordinasi dengan pihak LPMP Surabaya untuk bernegiosiasi tentang peminjaman tempat pelatihan, Hasil dari koordinasi ini didapatlah izin penggunaan LPMP.

Journal of Dedicators Community | 54 
Di hari pelaksanaan kegiatan ini dihadiri oleh 80 peserta yang terdiri dari perwakilan pengelola PAUD.

\section{Tahap Pelaksanaan}

Dengan persiapan kegiatan yang dilakukan kurang lebih selama empat bulan, akhirnya kegiatan Peningkatan Kapasitas Implementasi Kurikulum PAUD 2013 Tahun 2019 kerjasama Pimpinan Pusat Nasyiatul Aisyiyah dapat terlaksana pada Hari Jumat sampai dengan Ahad Tanggal 5-7 juli 2019 di LPMP Surabaya Jawa Timur. Kegiatan ini diawali dengan acara pembukaan yang dihadiri oleh Pimpinan Pusat Muhammadiyah, Sekjen Kemendikbud RI, Pimpinan Wilayah Muhammadiyah Jatim, Perwakilan Angkatan Muda Muhammadiyah (IPM, IMM, dan Pemuda), Himpaudi dan Organisasi kepemudaan lainnya.

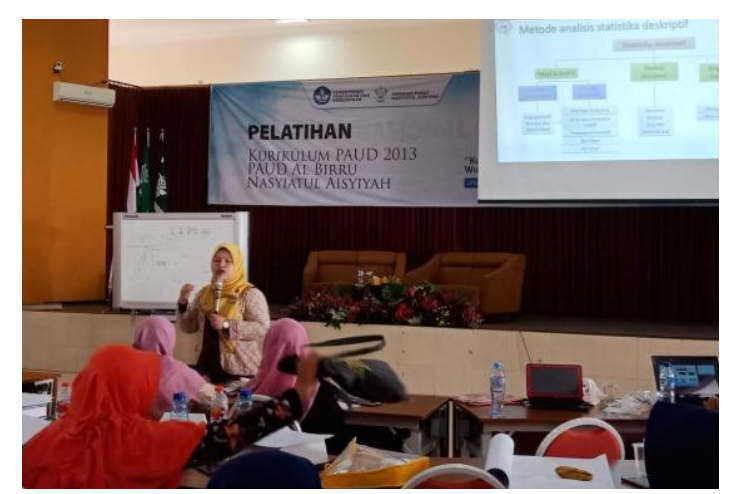

Gambar 1. Pelatihan Kurikulum PAUD 2013

Setelah acara pembukaan selesai dilanjutkan dengan acara Seminar nasional yang diawali dengan orasi ilmiah yang disampaikan oleh Wakil Gubernur Jawa Timur Bapak Emil Dardak, Dilanjutkan dengan diskusi panel yang disampaikan oleh PP Nasyiatul Aisyiyah dan Staf Khusus Menteri Kementerian Pendidikan dan Kebudayaan RI.

Kegiatan pelatihan dibuka oleh MOT, diawali dengan pembuatan kesepakatan kontrak belajar, Terdapat dua poin penting dalam kontrak belajar ini yaitu pertama datang tepat waktu, jika datang telat maka peserta akan diberikan punishment berupa games. Kedua, alat komunikasi menggunakan mode diam. Kegiatan dilakukan dengan metode pembelajaran orang dewasa. Setelah kontrak belajar disepakati, dilanjutkan dengan pre test yang dipimpin oleh fasilitator selama kurang lebih 20 menit, Pada akhir pelatihan dilakukan sesi rencana tindak lanjut dan diakhiri dengan post test dengan waktu yang sama dengan pre test.

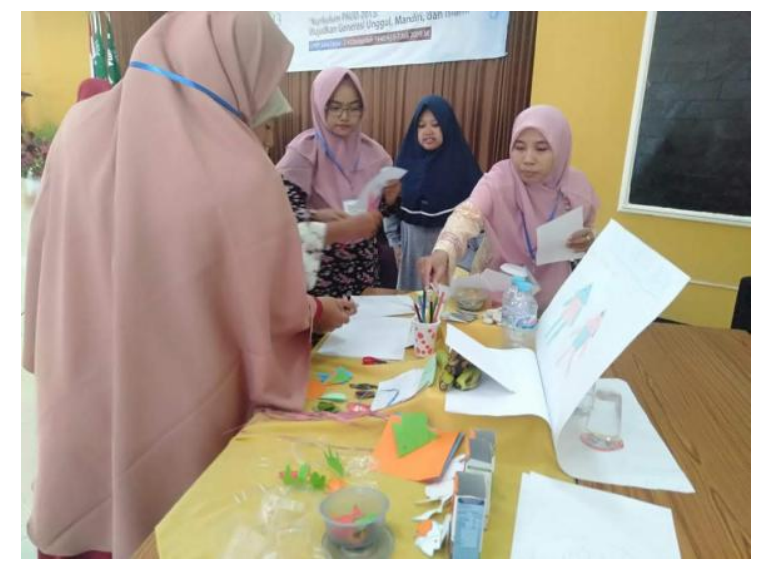

Gambar 2. Proses Pelatihan Kurikulum PAUD 2013 
Materi-materi dalam kegiatan ini diberikan oleh narasumber yang kompeten dalam bidangnya, baik yang berasal dari akademisi, praktisi maupun pemangku kebijakan. Berikut rincian materi program Pelatihan Kurikulum 2013 :

1. Pengelolaan Kelas Bermuatan STEAM dengan Menggunakan Loose Part

2. Pembelajaran Seni Untuk Anak Usia Dini

3. Pembelajaran Bahasa Untuk Anak Usia Dini

4. Pembelajaran Matematika Untuk Anak Usia Dini

5. Pembelajaran Ilmu Sosial dan Wawasan Kebangsaan Untuk Anak Usia Dini

6. Pembelajaran Sain dan Teknologi Untuk Anak Usia Dini

7. Perencanaan Pembelajaran dan Pengelolaan Administrasi Lembaga PAUD

8. Penilaian Pembelajaran dan Pelaporan Perkembangan Anak

9. Penilaian Pembelajaran Pengantar Penulisan Ilmiah bagi Guru PAUD

10. Micro Teaching

11. Rencana Tindak Lanjut
Selain materi-materi diatas dalam pelatihan ini pun diberikan materi tambahan tentang pengantar penulisan ilmiah. Materi ini diberikan berdasarkan permintaan dari para guru untuk mampu meningkatkan kapasitas dalam penulisan ilmiah untuk dapat berpartisipasi dalam berbagai lomba penuliasan karya ilmiah.

Dilakukan juga evaluasi dari hasil pembelajaran, dilakuan pula evaluasi terhadap proses pelatihan dengan dilakukan pengisian kuesioner tentang umpan balik.

Pada akhir pelatihan dilakukan pembahasan rencana tindak lanjut bagi para peserta. Hail dari diskusi diperoleh beberapa poin tindak lanjut sebagai berikut:

1. Setiap peserta wajib mensosialisasikan hasil pelatihan K-13 pada masingmasing lembaganya.

2. Waktu pelaksanaan sosialisasi selama 3 bulan (Juli-September)

3. Membuat laporan hasil sosialisasi secara tertulis dan melampirkan dokumentasi kegiatan.

4. PAUD al-Birru harus mencerminkan gerakan PAUD yang berkualitas, inklusif, berkesetaraan.

5. Pembentukan forum ikatan Alumni Pelatihan K-13 PAUD Al-Birru Nasyiatul Aisyiyah, dengan koordinator Ayunda Temon 
(Tulungagung), Mulia Dewi (Banten),

Halimatul Hasanah (Bondowoso)

\section{SIMPULAN}

Hasil dari kegiatan ini adalah terdapat perubahan pengetahuan tentang kurikulum 2013 PAUD pada para peserta pelatihan. Peserta memberikan penilai terhadap pelaksanan pelatihan pada umumnya baik. Luaran dari pelatihan ini para peserta wajib melakukan sosialisasi materi kurikulum PAUD 2013.

\section{DAFTAR PUSTAKA}

Ayob, A., Badzis, M., Nordin, A. L., \& Abdullah, R. (2016). Kurikulum Permata Negara.

Direktorat Pembinaan PAUD. 2014. Pengenalan Kurikulum 2013 Pendidikan Anak Usia Dini, Jakarta: Kementrian Pendidikan dan Kebudayaan RI.

Pedoman Pembelajaran Anak Usia Dini dengan Pendekatan Saintifik. Jakarta: Kementrian Pendidikan dan Kebudayaan RI. 2015.

Kerangka Dasar dan Struktur Kurikulum 2013 Pendidikan Anak Usia Dini. Jakarta: Kementrian Pendidikan dan Kebudayaan RI.

2014.
2015. Pedoman

Pengelolan Pembelajaran

Pendidikan Anak Usia Dini,

Jakarta: Kementrian Pendidikan dan

Kebudayaan RI.

J. Supranto. 2016. Statistk: Teori dan Aplikasi Jilid 2. Jakarta: Erlangga.

J. Supranto. 2016. Statistk: Teori dan Aplikasi Jilid 1. Jakarta: Erlangga.

Yuliani Nurani Sujiono. 2011. Konsep

Dasar Pendidikan PAUD. Jakarta:

PT Indeks 